\title{
Media Innovation in a Strange Place: Newspaper Differentiation on Åland
}

\section{Carl-Gustav Lindén}

Swedish School of Social Science, University of Helsinki

carlgustavı@gmail.com

\section{KEYWORDS:}

\section{ABSTRACT}

This essay examines the cultural, economic and political contexts of the small but vibrant media market on the Åland islands as well as competition strategies deployed by managers at two local Finnish newspapers, Ålandstidningen and Nya Åland. The case study has a managerial framework and aims to address four questions: 1) what is the foundation for newspaper competition at Åland; 2) what institutional drivers determine the way these organisations operate; 3) how do managers experience competition and innovation; and 4) what are the implications for society?

The essay is based on semi-structured interviews. The analysis shows that copying and imitation are an integral part of competition and it can be argued that competition leads to less, not more, differentiation, with highly substitutable goods produced for the same group of consumers. Imitation is known to be a common practice in the media world. There is evidence that news agendas in the Alland newspapers diverge only marginally from each other. However, it can be argued that competition is good for local democracy since there are at least two platforms available for public opinions. Local business can also gain from the fact that competition lowers prices for advertising space. In this sense a linear view of competition between media as a single explanatory framework for innovation and differentiation is not satisfactory. The dominance of one owner in both newspapers complicates the overall picture.

Media innovation, Media competition, Media imitation, Åland

The Journal of Media Innovations 2.2 (2015), 40-57. DOI: http://dx.doi.org/10.5617/jmi.v2i2.993 http://www.journals.uio.no/index.php/TJMI (c) Carl-Gustav Lindén 2015 


\section{ÅLAND AS A MEDIA MARKET}

The tiny Åland with its 6,500 islands and 28,900 inhabitants is an autonomous part of Finland bordering Sweden. However, it is one of the ten wealthiest regions in the $\mathrm{EU}$ and in terms of immigration the fastest growing in the Nordics after Iceland and Norway; the population has increased by $17 \%$ since 1990 (The Nordic Council, 2014). Åland, the smallest of three self-governed regions in the Nordic area, is characterized by a strong local culture and common identity (Wasström, 2002). Even though Swedish is a small minority language in Finland, as a whole the territorial dominance of the minority is not challenged (Moring \& Kivikuru, 2002). Main sources of revenue are shipping and tourism, more than two million visitors a year, representing $19 \%$ of GDP (Rundberg \& Kinnunen, 2014) as well as wholesale, banking, food production and software development. Politically Åland is centre-right with the only party to the left, the social democrats, receiving $18.5 \%$ of the votes in the 2011 local parliamentary elections.

This is also the only region in Finland with competition between same language newspapers, apart from the national evening press (Ilta-Sanomat and Iltalehti). In other regions and cities competition only takes place between daily newspapers published in different languages, Swedish and Finnish. Here, the market leader and legacy newspaper Ålandstidningen (established 1891) and challenger Nya Åland (established 1981) are competing head on.

Media supply on Åland can be seen as "institutionally complete", present on all relevant platforms with a diverse and rich content of good quality (Moring, 2007). It is a dense media market with around 60 journalists and four major media outlets. The ratio between the population and journalists on Åland is 466 to 1 compared with 2,241 to 1 in other European minority areas (Zabaleta, FerréPavia, Gutierrez, Fernandez, \& Xamardo, 2014b). This could also indicate an oversupply of news and other journalistic content.

The total value of the Åland newspaper market (advertisements in print newspapers and online as well as revenues from newspaper subscriptions) is estimated to be slightly over six million euros.

In addition to the two newspapers there is a public service company, Ålands radio och tv, founded in 1996 and financed with licence fees as well as a private radio station, Steel FM.

Generally minority media in Europe is mostly publicly funded, with privately owned and socially owned media being less common (Zabaleta, FerréPavia, Gutierrez, Fernandez, \& Xamardo, 2014a). In that comparison, the media landscape in Åland appears as balanced. 


\section{LITERATURE REVIEW}

Newspaper competition is a topic broadly abandoned by media researchers and most of the literature is dated, indicating that the decline of newspaper rivals in the same area has been a long process (Engwall, 1981; Lacy, Shaver, \& Cyr, 1996; Rosse, 1980). For instance, in Sweden only four competitive places remained for paid newspapers in 2013 (Thorén, 2014). Overall, competition between media is weak compared with other industries (Picard, 2011: 155). However, there is a renewed interest among economists in newspaper competition (Argentesi \& Filistrucchi, 2007), especially in the two-sided markets where media compete for both readers and advertisers (Anderson \& Gabszewicz, 2006). Newspapers have been able to subsidise journalistic content by charging advertisers for access to consumers.

Against this backdrop, Åland offers a rare possibility to explore the dynamics of rivalry and coexistence that existed in the newspaper market before consolidation of dailies started in the late 1970s (Salokangas, 1999).

In theory competition creates needs to develop new products and services, but here lays a contradiction to practice. According to Schumpeter (1934) innovation should decline with fiercer competition, while empirical evidence suggests that increased competition stimulates innovation as well as research and development (Aghion, Bloom, Blundell, Griffith, \& Howitt, 2005; Tingvall \& Poldahl, 2006). It has been noted that media competition induces vigour but leads to diminishing returns; lower prices, additional features or other changes in products and services that mainly benefit customers (Picard, 2011, 76). A lack of competition could mean stronger profits and more resources for innovation, but can also cause organisational inertia and failure to respond to technological change, among other problems (Küng, 2007, 115).

A key concept in competition is differentiation which allows companies to position their offering so that consumers can distinguish this from what the competitor is selling, be it price, quality, usability, image, convenience or service. As part of the cultural industries newspapers can differentiate in the manifestation of political, cultural and social preferences which, if honest, represents an authentic expression of organisational culture. Economic models of product differentiation propose that firms face two opposing incentives: (1) minimise differentiation in order to "steal" customers from competitors, and (2) maximise differentiation in order to reduce price competition (Borenstein \& Netz, 1999). The first incentive, to imitate, is common in the media business, leading to content homogenisation (Boczkowski, 2010).

Competition and innovation are closely linked concepts. According to Best (1990), the focus on price represents "old competition", whilst he labels a focus on quality, innovation (and creativity) the "new competition". Innovation in journalism and media as a source of competitive advantage has become a prominent research subject in recent years and there is tremendous opportunity for innovation and learning (Gynnild, 2014; Kauhanen, Kaivo-Oja, \& Hautamäki, 2007; Meier, 2007; Nordfors, 2004; Picard, 2010; Picard, 2011; Westlund \& Lewis, 2014). Technical equipment and content software are becoming cheaper and easier to use, the marginal cost of digital distribution, processing power and storage capacity is negligible and the appetite for new things among the audience is growing. Most newsrooms have also reached a critical mass in technology in terms of general computer use and adoption of online resources (Garrison, 2001). Still, the lack of a consistent innovation management strategy seems to be common in the newspaper industry (Adams, 2008) and this is obvious, for instance, in the leaked New York Times 
innovation report (Sulzberger, 2014). For legacy media accustomed to a relatively stable working environment the digital transformation is often felt as a threat and convergence (Jenkins, 2006), the leap from print to digital publication as well as integration of different content, audience and producers is indeed a challenge for both journalists and publishers. The slogan "digital first" is being replaced by "technology first", indicating that media companies of the future will need to develop their own technical solutions (Solis, 2014).

While technology is important, the primary brakes on media innovation are mostly cultural, sitting within the newsroom; research suggests that they are systemic and rooted established practices and preferred work patterns (Ess, 2014) and that the ideology of journalism practice is embedded in a particular form of production (Thorén, 2014). Switching the newsroom mindset from products to services, from hardware to software, and from audience to users is not an easy endeavor. Experiments with what works and could work in terms of securing financial resources are producing mixed results and there is no successful single recipe of media transformation and adaptation (Holm, Ulhøi, \& Uliyanova, 2012; Storsul \& Krumsvik, 2013; Thorén, 2014).
Besides the cultural values and ideology of an organization two other factors determine the capacity for change: its resources and processes (Christensen \& Overdorf, 2000, 68). Research on innovation in Norwegian newspapers (Krumsvik, Skogerbø, \& Storsul, 2013) indicates that there is a stronger stimulus for innovation in large media companies compared to small, independent newspapers. The success of minority media, because of small size, is restricted by limited audiences and scarce financial resources such as advertising revenues (Zabaleta et al., 2014a). Most innovation categories (product, process, packaging, and pricing) are built on the assumptions of affluence and abundance, not scarcity. Therefore it makes sense to analyse minority media within a scarcity framework.

Finally, there is a need to critically evaluate the concept of innovation. The pairing of creativity and innovation is seen as something of a "magic bullet", as a solution to all problems (Pratt \& Jeffcutt, 2009, 3). Relatively straightforward invention and design is also often confused with innovation (Nyre, 2014). I will here use the term innovation in a limited sense, as design of new services and products or improvements of existing supplies rather than as a research framework for "social and structural conditions that shape communication" (Trappel, 2015, 15). I back up my argument with evidence that radical innovation, something totally new, is often taking place outside traditional companies, such as newspapers, which are more focused on incremental innovation, that is, improvements of what they already did before while only slowly adapting to digital transformation (Norman \& Verganti, 2014). 


\section{DATA AND METHOD}

This study is based on one set of primary data, analysed with qualitative methods, and on secondary newspaper circulation data as well as secondary data provided by the newspapers. The primary data was generated through repeated in-depth semistructured interviews $(n=6)$ with managers about competition and innovation. A fixed set of themes was developed to make sure that the categories were consistently covered - namely, innovation, competition, differentiation, and societal implications. The interviews were conducted in April 2012 with a follow up in January 2014 to record change over time.

At Ålandstidningen the editor-in-chief Niklas Lampi and the managing director Dan-Johan Dahlblom were interviewed. At Nya Åland Jonas Bladh, who was in charge of all operations, both business and editorial content was interviewed together with his deputy Nina Fellman, former editor-inchief. Stefan Norrgrann, who at the moment was in charge of developing and operating web based television, was interviewed only in 2012.

The local business tycoon, Anders Wiklöf, who is the largest owner in both newspapers, was inter- viewed twice. After the second round of interviews Nina Fellman decided to leave the newspaper to become a candidate for the social democrats in the local election. Dan-Johan Dahlblom was appointed the CEO of two companies for daily goods, wholesale and ship supply owned by Anders Wiklöf, Mathias Eriksson and Mariehamns Parti.

Audio records of interviews were transcribed by a research assistant and texts were broken down in parts so that data could be compared, conceptualized and categorized. After that statements were interpreted and contextualised within broader frames of reference instead of just providing a categorisation (Kvale, 2007). The meaning of the interview texts goes beyond a structuring or description of the manifest meanings of what is said.

Why the managerial perspective? A common understanding is that leaders have crucial impact on the culture of any organization, the shared values, beliefs, behaviour expectations and sense of purpose that permeates every level (Martins \& Terblanche, 2003). Managers can encourage and reward creative thinking, but also in many ways discourage attempts to innovation.

For the analysis of newspaper circulation and audience reach, statistics from Levikintarkastus
(2013; 2014) were used as well as secondary data from the yearly national phone based media consumer survey (TNS Gallup, 2014). Financial data on newspaper operations was subtracted from the web pages of the companies (Ålands TidningsTryckeri Ab, 2015; Nya Åland, 2015).

The preliminary findings from this study were tested and evaluated in a group debate with around twenty local journalists in December 2014 and the discussion helped the author to rethink some of the arguments in this essay. These journalists participated in an event open to members of the local association for journalists and they represented newspapers as well as radio and freelancers. The debate was moderated by the author. 


\section{CHARACTERISTICS OF THE TWO} NEWSPAPERS

Following here are case descriptions of the two newspapers which, despite having the same dominant owner, try to differentiate with diverging editorial and business logics. The local business tycoon Anders Wiklöf, who is the largest actor in the market for daily goods, is together with two different business partners the largest owner of Ålands Tidnings-Tryckeri, which publishes Ålandstidningen, and Nya Ålands Tidningsaktiebolag, publisher of Nya Åland.

Ålandstidningen was established in 1891 and one co-founder was a local political activist, Julius Sundblom, considered the "King of Åland" due to his advocacy for separatism, and who also was the editor-in-chief for three decades. The challenger Nya Åland was launched in 1981, originally as a cooperative by discontent journalists at Ålandstidningen (Forsgård, 2006; MattssonEklund, 1991), and was forced from the very beginning to be creative and lean in producing, printing and distributing the newspaper. This new venture also divided the Åland population in two parts: Ålandstidningen or "Gamlan"- the old one or the blue one (the colour most frequently used in design and marketing) - was considered more conservative and friendly to the establishment while "Nyan" - the new one or red one - was seen as more modern, left-leaning and feminist. These are important internal and external images that managers sometimes have struggled to change. For Nya Åland it is, for an example, risky to differentiate with political preferences to the left since the social democrats are a relatively small party on the local level.

Competition has been fierce and no common ground found during the years. For instance, only in the summer of 2014 did they decide to merge printing operations.

Readers have shown frustration with the ongoing brawl between the papers (Luther, 2009) that at time develops into the type of political hyperdifferentiation that, as research shows, might place tensions on public discourse and undermine deliberate local democracy (Conboy \& Steel, 2008). On the other hand the competition might inspire journalists in both newsrooms to do their very best, something reflected in the fact that both newspapers regularly manage to win the national prize for best Finnish local newspaper.
Case Ålandstidningen

Ålandstidningen is published six days a week and the circulation, according to the latest official audit in 2011 by Levikintarkastus was 8,829 distributed copies. The company stopped participating in the audit the following year and on its web page (Ålands Tidnings-Tryckeri Ab, 2015) claims to have a circulation of 9,577 copies. Ålandstidningen employed 20 journalists in the beginning of 2014. As the market leader Ålandstidningen is much better positioned to attract advertisers and ask for higher advertising rates.

Together and separately Anders Wiklöf and his business companion Ben Lundqvist control around $37 \%$ of all shares in Ålands Tidnings-Tryckeri, which is listed on the local informal stock market. Altogether that company has more than one thousand shareholders.

Ålandstidningen represents a purely commercial business model. The owners expect a healthy rate of return on money invested, which the company has been able to deliver. During the last decade Ålandstidningen has managed to financially stay in the black except for one disastrous year, 2007, and by 2011 it was already making a record profit. The newspaper was actually the only Swed- 
ish language paper out of nine in Finland to make a profit in 2013 (Sjöholm, 2014).

The turnover in 2013, which includes an advertising agency, was 6 million euros (6.5 million euros in 2012), and the operating profit 0.6 million euros with a profit margin of $10.6 \%$. Around $60 \%$ of revenues are generated through advertisement while only $3-4 \%$ was generated online. The commercial strategy is to uphold profits and financial stability while gradually and carefully teaching readers as well as advertisers to adopt the electronic version of the newspaper, which is accessible only through a non-permeable paywall.

The newspaper takes a classic liberal view on society while editorial values are based on quality, tradition, institutions and seriousness. Politically Ålandstidningen represents an expansive view on the political development of the region and advocates a stronger autonomy.

\section{Case Nya Åland}

Nya Aland is the smaller newspaper with a circulation of 6,464 copies in 2012, which was the last year with officially audited numbers. In 2011 the circulation was 6,683 . The paper version is published five days a week.
The readership of Nya Åland is much smaller than Ålandstidningen in the countryside, but almost equally strong in the local capital, Mariehamn. In the beginning of 2014 the newspaper employed 21 journalists, of which six were part-time.

Together with the wealthy cultural foundation Konstsamfundet, Anders Wiklöf is likewise the largest owner of Nya Åland with a combined ownership exceeding $70 \%$. Konstsamfundet is also the owner of KSF Media in Helsinki, a holding company for three Swedish-language and one Finnish-language regional newspaper published in Finland. In Nya Aland the owners have accepted losses for many years and the newspaper business model includes a mixture of philanthropy, patronizing, and public subsidies with social and commercial ingredients. Nya Åland considers itself a newspaper owned by the readers and has around 800 owners altogether. Shares are traded on the local stock market.

Nya Åland has only once made a profit during recent years, 2008-2013. Total loss of the company in 2012 was 0.16 million euros. For 2013 numbers turned downwards and its television operation was still waiting to break through financially. The losses increased to 0.33 million euros. In late 2014 the company decided to sell its company headquarters and reduce the workforce to trim costs. In early 2015 Nya Aland also decided to replace two of its five printed daily editions with online versions.

The newspaper could probably not survive in its present format without the support from its owners.

Revenues in 2013 amounted to 3.06 million euros (2.85 million in 2012), of which about $4 \%$ came from online activities.

The newspaper has a left-leaning to liberal view on society and tends to support the social democrats. Its view on autonomy is realistic and situated within the given administrative and political space. Compared with Ålandstidningen the newspaper looks more entrepreneurial, looking for new, interesting and fun things to pursue. 


\section{NEWSROOM CULTURE AND DIFFERENTIATION}

In the following part this essay will analyse organisational culture and how it materializes in editorial processes and differentiation manifested in political, cultural and social preferences. Organisational values, beliefs and images - how we do things over here - is a decisive element of innovation (Martins \& Terblanche, 2003).

Nya Åland is forced to be innovative because of its role as the challenger, despite obstacles to developing new sources of revenue. The newsroom seems to be a place where the start-up hymn "act fast, fail fast, learn fast, and recover fast" is part of the culture. Nina Fellman said she is "blessed with a capability to forget all catastrophes."

It is better to test things than not to and never get anything done. A newspaper is like a mayfly; if something goes wrong one day it is not the end of the world. You have to dare to try even though you might find out it was just crap.

The managing director Dan-Johan Dahlblom at Ålandstidningen openly admitted to being impressed with the newsroom culture at Nya Aland where journalists sacrifice economic benefits for the sake of keeping the newspaper alive.

That cooperative culture is more based on emotions, but at the same time a hell of a strong force because they can publish the newspaper even though there are hardly any people in place. Everything we do we calculate [...] we have a strong machinery; when we do something [...] we have an economic plan behind most things.

There does not seem to be any formal strategy for innovation at Nya Åland, just an institutionalized underdog capacity to generate and implement new ideas, an openness to change (Polansky \& Hughes, 1986). A lack of strategy is not uncommon among newspapers (Adams, 2008). However, even though resources are limited, Nina Fellman said she believes that if newspaper printing ended tomorrow they would find a way to survive that as well. She noted that with little means comes the necessity to be flexible and economical. For instance, when Nya Åland decided to set up a television studio it was equipped with cameras, sound system and lighting bought cheap from a bankrupt company. It comes somewhat in line with "frugal innovation", the term used for the process of reducing the complexity and cost of a good and its production - achieving more with fewer resources (Kumar \& Puranam, 2012, 114). At Nya Åland they have even named the frugal process after a local ship owner who operated the world's largest fleet of commercial sailing ships in the 1930s:

All along we have used Gustaf Erikson's method. We run old junk that others have discarded; it is cheap and it works. I do not think that we as a small local newspaper with little resources can be cutting edge when it comes to technology.

The financial support from the owners enables the newspaper to continue making losses. Lampi picked the online market places Marknaden (Ålandstidningen) and Torget (Nya Åland) as an example of business potential destroyed due to this fact. Readers do not pay to advertise their goods: "We are stuck with this structure. We have different business philosophies - to Nya Åland it is not a problem that some things are free."

The managers at Nya Åland admit that they are less concerned with the financial side of operations, though not reckless.

As the second newspaper in its region Nya Åland received yearly state support for distribution 
until 2008 while Ålandstidningen received 50,000 euros in special state support in 2009. In Finland the government abolished press subsidies in 2007 and replaced it with financial support for political communication. In 2012 a 9\% VAT on printed newspapers was introduced and since 2013 the VAT is 10\% (Virranta, 2013).

Development of television services at Nya Åland has been supported with public and institutional R\&D money. First P24 Media Ab, the local company that originally worked to develop new services for Nya Åland, received support from the $\mathrm{EU}$, matched by the local government, to develop a media platform for local multichannel broadcasting. The company merged with local TV channel Åland24 in 2009. The original platform has been replaced with another one provided as a service. In addition to this Åland24 has received around 300,000 euros from Konstsamfundet and another foundation, Svenska kulturfonden.

Ålandstidningen, on the other hand, is quick to examine new forms of media explored by the competitor, and copy those that are considered profitable. In that sense Nya Alland is an innovation test bed. The success of new products and services is unpredictable and therefore this is a way for the legacy newspaper to reduce uncertainty.
These newspapers also represent the two types of differentiation: Nya Åland tries to avoid a price competition it will lose by pursuing other ways of differentiation while Ålandstidningen wants to reduce differentiation and persuade customers both readers and advertisers - with an image of quality for money. This illustrates how competition can lead to less, not more, differentiation, with highly substitutable goods produced for the same group of consumers (Boczkowski, 2005; Picard, 2011). Said Niklas Lampi: "If Nya Åland comes up with something, then we shall do the same, but better [...] regardless of the risk that we are considered copycats."

Here are a few examples of innovation as imitation. A brief encounter with journalists in the Nya Aland newsroom in April 2012 revealed that they felt that Ålandstidningen was reaping the fruits of their labour by "stealing" ideas for content. During a 20 minute discussion journalists came up with almost a dozen examples, ranging from the market place "Torget" to "Messa Nyan", the site where readers can use SMS messages to convey their thoughts. Other examples of content copied was capturing new-born babies on photo and publishing them ("Ny på Åland”) and "Pejlingen”, a voter survey conducted before political elections. But someone remarked: "To be fair, we steal too".

Intensified differentiation

During the second round of interviews, in January 2014, the two newspapers were exploring new ways to differentiate with format, content and distribution. Both newspapers had introduced iPad and Android apps for tablets and mobile phones. Nya Åland put resources into its daily news and weather cast at Åland24 distributed through the web, cable and terrestrial networks. News, sport, debate and lifestyle programmes were produced every day during the working week by two journalists and two salespersons/producers.

One way of reducing competition is to break free from spatial boundaries by expanding the market size, something Nya Åland tries to do. Åland24 has broadened its coverage to the south-western part of Finland in the Turku archipelago to reach an additional 30,00o households. At the same time the company has made (so far, fruitless) attempts to sell lean television production as a service concept. The newspaper also produces news from the islands for the Finnish national news agency STTLehtikuva and until recently had a similar contract 
with the Finnish broadcasting company, Yle, to deliver television news.

Ålandstidningen, for its part, used resources to develop the new digital edition and readers reacted quite positively according to Niklas Lampi. Somewhat disappointingly for the publisher advertisers were still slow to follow and they preferred print, illustrating that advertisers might be as conservative as newsrooms. The newspaper had started experimenting with video clips on the web page, even though not planning a full-fledged television concept. The newspaper also added sponsored content known as advertorials or native advertising. These are pieces of advertisement dressed like editorial content, a practice copied from digital editions of Swedish newspapers and one of the paths to new business models for media, breaking down the news-business boundary (Coddington, 2015; Couldry \& Turow, 2014).

Overall, the competition for content seems fierce; in the group discussion journalists from the newspapers admitted to constantly checking each other's websites, not just every hour but "every ten minutes", as one participant said.

\section{MARKETS FOR READERS, ADVERTISERS,} NEWS, SPONSORSHIPS AND EMPLOYEES

From a traditional media economics perspective newspapers are active in the two-sided markets for readers and advertisers (Anderson \& Gabszewicz, 2006), producing audiences that will attract marketers of services and products. As the market leader Ålandstidningen is much better positioned to draw readers and advertisers. In the local market there are between 200 and 300 companies that regularly do marketing campaigns. The biggest advertisers are travel and retail companies, among them Mathias Ericsson owned by Anders Wiklöf.

It should be noted that at least three other markets exists; the markets for news and sources, sponsorships and employees. In the case of Åland the market is small for sponsorships that will enhance the external image of newspapers. Ålandstidningen is, for instance, sponsoring the main male soccer team Mariehamns IFK while Nya Åland has chosen to support the female soccer team Åland United. Equally small is the labour market for journalists: employees mainly transferred from Nya Åland to Ålandstidningen in search of better career opportunities and job security.
In the following part the audience market and the market for news and sources will be examined.

Competition for readers

After a strong start, followed by a long decline in the 1990s, Nya Åland managed to gain substantially in the beginning of the new millennium. Nya Aland increased the number of subscribers by $8.8 \%$ between 2000 and 2005 while Ålandstidningen was losing $10 \%$ of its circulation during the same period (Levikintarkastus Oy, 2013; Levikintarkastus Oy, 2014). In 2007 Nya Åland introduced its sixth daily edition and was getting close to overtaking Ålandstidningen. But on April 14, 2007 the "blue one" did something seemingly trivial but quite radical that changed the playing field altogether; it became a morning newspaper like Nya Åland. It was a desperate move. The local mail carrier raised costs for distribution and Ålandstidningen decided to compensate its readers for higher prices by introducing a Saturday paper. Nya Åland surprised everybody by introducing a Saturday edition within weeks. Dan-Johan Dahlblom at Ålandstidningen recalls the moment and the predatory price war that followed: 
They did not really calculate it, we were fighting ourselves bloody, we dumped rates for advertising as well as subscription fees and I would say that we have not recovered from that until recently; in 2010-2011 it started to look pretty good.

This did not stop the circulation of Ålandstidningen from dropping further, but it prevented the rise of Nya Åland, which due to miscalculations later had to reduce its frequency from six to five days a week by abolishing the Saturday edition. Stefan Norrgrann at Nya Aland explains as follows:

Until then we kept our position while they lost - but after that we lost as well. Between 1998 and 2008 we could differentiate as a morning newspaper, they as an evening newspaper.

Even though circulations are down both newspapers still attract a large part of the population. Of 14,00o households on Åland around 4,00o do not subscribe to any daily newspaper which means that the newspaper coverage is more than $70 \%$. Around $10 \%$ of the readership is the Åland diaspora living in Sweden which adds up to between 4,000 and 5 ,ooo households in the region reading both news- papers. In addition to these two newspapers the national Swedish-written daily Hufuudstadsbladet, owned by the foundation Konstsamfundet, was in 2012 also distributed to 1670 subscribers on Åland, down by $29 \%$ since 2008 . In 2010, the newspaper ran trials to replace the expensive printed newspaper with an e-paper distributed on reading devices (Härmälä, Helle, Heikkilä, \& Hytönen, 2012).

Further, around 11,00o persons on Åland are reading a Swedish newspaper at least three times a week and another 1,600 a Finnish newspaper (Luther, 2009). In Mariehamn in 2012 people were reading two or three daily newspapers. The situation is not atypical since outside the capital in one of the larger municipalities, Finström, these newspapers even had a household coverage of $141 \%$, which certainly makes the small region a vibrant object of newspaper study.

Both papers do marketing campaigns on a regular basis which means that potential readers are bombarded with cheap offers to subscribe. Dan-Johan Dahlblom said there is a group of between 500 and 1,00o people who are active "price hoppers":

I think the competition sometimes goes a bit mad; it can go so far that we teach an increasingly larger group of customers to sit and wait for someone to call, or to get a coupon in the mail box with a nice offer.

Citizens express great interest in what happens in the local community (Wasström, 2002) but newspaper competition and diversity of news and opinion might not be enough of a reason to buy the paper. Between 2004 and 2011 Ålandstidningen lost $16 \%$ of its circulation and Nya Åland 8\% compared with a decline of $11 \%$ in Finnish newspapers overall. It is worth noting that neither Nya Aland nor Ålandstidningen has been able to attract new groups - youth and immigrants - as subscribers.

Competing with news

Research conducted before the Internet arrived showed that newspaper competition remains important for encouraging diversity of views on public issues (Lasorsa, 1991). Journalists tended to think that competing dailies provide higher quality local news, a greater diversity of news, and a greater diversity of editorial opinions than non-competitive dailies (Coulson \& Lacy, 1996). A Swedish survey showed that journalists employed by commercial media companies were more inclined to have a positive view of competition than journalists in public service (Asp, Weibull, \& Kulturdepartementet, 
1996). Competition has changed radically with public access to an almost unlimited amount of news sources. The industry has been going from a model of news demand in near monopoly markets (Lacy, 1989) to a model of almost infinite news output. However, it should be noted, local news is still not mass produced but subject to laborious methods, thereby bordering on an artisanal handcraft.

Åland has 16 municipalities as well as a local government and parliament which translate into a relatively large public administration and a fertile ground for news making; there is a wide scale of events and opinions. According to Nina Fellman at Nya Åland "no politician on any level in Finland is scrutinized as much as our politicians on the municipal level". Otherwise the newspapers a have a more relaxed attitude towards what is news compared with some other newspapers in Finland; content does not have to be that serious, she noted.

A qualitative study of media output at Åland (Rothberg, 2010) indicates that half of the content in Ålandstidningen, Nya Åland and Ålands radio och tv was unique in 2007-2008 and where reporters dealt with the same events they used different sources and news angles. Looking at crime stories Ålandstidningen had five times more than Nya Åland. However, Niklas Lampi believed that when it comes to news both newspapers use the same criteria and articles are actually to a large extent overlapping; there is little evidence of radically diverging news agendas.

Still, I tend to experience that "Nyan" in their news coverage is inclined to turn a little bit more to the left in some issues. Nina Fellman is a strong and capable newspaper manager, but her perspective of reality tends to shine through in the newspaper.

Two different platforms for voice and views are available, thus supporting diversity of opinion, political competition and strengthening local democracy. This is, for instance, reflected in the editorial policy where the "old" is geared towards greater regional autonomy while the "new" advocates a more pragmatist approach in dealing with the central governmental powers in Helsinki. On the other hand, there is also reason to believe that the local community is somewhat polarised and split into separate groups. A previous editor-in-chief at the paper is nowadays a politician who campaigns for an independent Åland, while his successor Niklas Lampi said that this is unrealistic; an extended autonomy is the best solution.
Engagement with readers

Åland is a small community, but when it comes to engagement with its readers Nya Åland seems to be a special case compared with Ålandstidningen. Says Nina Fellman:

At some point I described it as when you go to the grocery store on a Saturday and have to run the gauntlet between the cucumbers and the tomatoes. I am not exaggerating. It never happens that no one would come and talk to me when I am shopping.

Despite that engagement she admitted being disillusioned as web comments by readers make her feel miserable, not an uncommon reaction among journalists (Binns, 2012). These feelings serve as an illustration of the troubled link between traditional journalism and user-generated content as a form of deliberate democracy and the limited involvement of citizens in news making (Domingo et al., 2008; Jönsson \& Örnebring, 2011).

There is almost no one else but the trolls there [...] they have these pseudo-debates between themselves and their aliases [...] during my time at "Nyan" I have promoted maximum transparency and have allowed a lot, but I think it is only getting worse. 
Nya Åland had started to question if newspapers should be enablers for people who refuse to accept any rules of engagement. After this discussion in January 2014 Nya Åland decided to introduce mandatory registration for people who wanted to comment on articles. And in the summer of 2013 the editor-in-chief Jonas Bladh of Nya Aland concluded that time had come to put an end to SMS messages to "Messa Nyan" since the site had been taken over by anonymous people spreading toxic thoughts. The decision was done after a consultation with readers. Instead a new form of letters from the public was introduced, one requiring comments sent by SMS to be signed.

\section{IMPLICATIONS FOR SOCIETY}

In this last section we will discuss what makes Åland a "strange place" for media innovation. Media density is one reason, the role of one owner another. The business person who controls the local media market, Anders Wiklöf, said he is on a democratic mission: two newspapers in competition contribute to a more vibrant discussion on public affairs - the more media, the more democracy: "I want people on Åland to have the option of two newspapers; they will be able to have their say. [...] But this has cost Anders Wiklöf some money," he said in the 2014 interview, talking about himself in third person.

Wiklöf has also been thinking about combining the two papers, a trend which has been prominent in Sweden where former competitors share the same premises and owner while pursuing different editorial paths (Alström \& Nord, 2003). In 2012 Wiklöf said he had been invited to the Swedish island Gotland where the two regional newspapers - Gotlands Allehanda and Gotlands Tidningar - share the same building but keep their names. Still, daily operations are supported with state press subsidies and papers would not survive without these (Press Commission 2004, 2006). In
2014 Anders Wiklö said he had decided not to accept the invitation and prefers to keep the Åland newspapers separate and accept financial losses at Nya Åland, something his business associates were not happy to hear, he noted: "But I tell them it is my money." To this should be added that his now deceased brother was a journalist and later a politician for the social democrats.

This sacrifice is seen as a problem by the competitor. Said Niklas Lampi at Ålandstidningen:

It is a fact that Anders Wiklöf actually draws profits from us and feeds them to Nya Åland; now he forgave 365,000 euros in debts [...] which of course creates certain bitterness here at Ålandstidningen.

Lampi has devoted at least one editorial (28 April 2012) to the intriguing relationship between the business tycoon, the foundation Konstsamfundet managed by Kaj-Gustaf Berg, and the other newspaper, writing that:

Nya Åland still prefers to tell the lie that it is a newspaper owned by "their readership". Then it does not look to well that today two readers (if we assume that Kaj-Gustaf Bergh is also reading Nya Åland) totally dominate the newspaper. 
Lampi accused Anders Wiklöf of mixing his power in the newspapers with his other business ventures. Still, Niklas Lampi said in the interview he is basically looking at the overlapping ownership and separate newsrooms in a positive light. Niklas Lampi is a family friend who knows the businessman from early childhood, as his father has been managing Wiklöf's business empire since 1992:

Anders is not mixing his roles and he is not problematic in the sense that he says what people should write in the newspaper [...] But Nya Alland has gained quite much from him; he has been the Knight in shining armour during most of 2000's and they are in debt to him, you can see that.

Anders Wiklöf, who controls most of the market for daily consumer goods on Åland as well as the Baltic ship supply and employs around 650 people, acknowledges that competition between the two papers keeps advertisement costs down. Therefore there is a commercial logic behind subsidies to the smaller loss-making newspaper. Wiklöf said he never writes letters or sends email to journalists to tell them what to write, but he refuses to be a neutral owner and argues strongly against tabloid journalism: "I want them to write positive stuff and an owner has the right to talk about policy." Intuitively, he might experience what is research evidence; negative news has more impact on consumer sentiments than positive (Hester \& Gibson, 2003) and it makes sense for retailers to prefer primarily positive news.

Media scholars within the field of political economy tend to believe that businesses use all means, such as advertising, to assert control over news directly and through self-censorship (Craig, 2004; Croteau \& Hoynes, 2001). In this specific case the wall between news and business might be more imaginary or porous than journalists or the owner want to admit, though not subject to the most blatant forms of special treatment or self-censorship. Anyhow, it is not possible to neglect the importance of one person for upholding the newspaper duopoly and enabling diversity of opinion. Local policy makers are discussing funding public service (Lundberg, Jansson, Lindqvist, \& Johansson-Gammals, 2011) and it could be argued that within this context they need to reflect upon a future without the individual that safeguards the present media situation.

\section{CONCLUSIONS}

This essay has shown in detail how differentiation can be used as one element in competition and innovation where newspapers try to find new ways of gaining market share. The small but vibrant media market on Åland has been presented as the study object. Four questions were answered. The first one, why there is newspaper competition at Åland, has its historical roots in journalists leaving the legacy newspaper, Ålandstidningen, to create a new one, Nya Åland. Journalists have, for instance, sacrificed some wage benefits to be able to keep the newspaper in business. In recent years a benevolent business man and a foundation have been supporting the company financially. Without that support from owners it is difficult to see that Nya Alland would survive. The role of the business man is intriguing as he, in his own words, supports competition in the name of diversity, but on the other hand gains from lower advertising costs.

These historical roots also explain the differences in newsroom cultures where Nya Åland has been forced to be lean and innovative to differentiate its product in other dimensions than price, where it cannot compete with the financially stronger rival. Managers at both companies feel that 
everyday competition is fierce but vitalising; while at Ålandstidningen they also criticise the other for destroying business opportunities. The study indicates that resources and processes might be less important factors than organisational culture when we discuss the capability and appetite for innovating new services and products. However, two obvious conclusions can be drawn: competition has not stopped the downturn in newspaper circulation and innovation in a traditional newsroom framework does not generate new resources quickly. In this sense a linear view of competition between media as a single explanatory framework for innovation and differentiation is not satisfactory.

In the answer to the fourth question, implications for society, it can be argued that competition is beneficial for local democracy. Further, local business can gain from the fact that competition lowers prices for advertising. The influence, direct or indirect, of one dominant owner with business interests, arguably quite benevolent, also ensures that competition to the death will not take place.

\section{REFERENCES}

Adams, J. W. (2008). Innovation management and U.S. weekly newspaper web sites: An examination of newspaper managers and emerging technology. International Journal on Media Management, 10(2), 64-73. doi:10.1080/14241270802000454

Aghion, P., Bloom, N., Blundell, R., Griffith, R., \& Howitt, P. (2005). Competition and innovation: An inverted-U relationship. The Quarterly Journal of Economics, 120(2), 701-728.

Ålands Tidnings-Tryckeri Ab. (2015). Åland: Om koncernen [Åland: About the company]. Retrieved from http://www.alandstidningen.ax/koncernen

Alström, B., \& Nord, L. (2003). Den skånska modellen: En VD, två kulturer, tre tidningar och fyra bröder [The Scanian model: One CEO, two cultures, three newspapers and four brothers]. Sundsvall: Demokratiinstitutet.

Anderson, S. P., \& Gabszewicz, J. J. (2006). The media and advertising: A tale of two-sided markets. Handbook of the Economics of Art and Culture, 1, 567-614.

Argentesi, E., \& Filistrucchi, L. (2007). Estimating market power in a two-sided market: The case of newspapers. Journal of Applied Econometrics, 22(7), 1247-1266.
Asp, K., Weibull, L., \& Kulturdepartementet, S. (1996). Svenska journalister om mångfald och medier [Swedish journalists on diversity and media]. Stockholm: Rådet för mångfald inom massmedierna.

Best, M. H. (1990). The new competition: Institutions of industrial restructuring. Cambridge, Mass.: Harvard University Press.

Binns, A. (2012). Don't feed the trolls! Journalism Practice, 6(4), 547-562. doi:10.1080/17512786.2011.648988

Boczkowski, P. J. (2005). Digitizing the news: Innovation in online newspapers. Cambridge, MA: MIT Press.

Boczkowski, P. J. (2010). News at work: Imitation in an age of information abundance. Chicago: The University of Chicago Press.

Borenstein, S., \& Netz, J. (1999). Why do all the flights leave at $8 \mathrm{am}$ ?: Competition and departure-time differentiation in airline markets. International Journal of Industrial Organization, 17(5), 611-640.

Christensen, C. M., \& Overdorf, M. (2000). Meeting the challenge of disruptive change. Harvard Business Review, 78(2), 66-77.

Coddington, M. (2015). The wall becomes a curtain: Revisiting journalism's news-business boundary. In M. Carlson, \& S. C. Lewis (Eds.), Boundaries of journalism: Professionalism, practices, and participation. New York: Routledge. 
Conboy, M., \& Steel, J. (2008). The future of newspapers: Historical perspectives. Journalism Studies 9(5), 650-661.

Couldry, N., \& Turow, J. (2014). Advertising, big data and the clearance of the public realm: Marketers' new approaches to the content subsidy. International Journal of Communication, 8, 1710-1726.

Coulson, D. C., \& Lacy, S. (1996). Journalists' perceptions of how newspaper and broadcast news competition affects newspaper content. Journalism \& Mass Communication Quarterly, 73(2), 354-363.

Craig, R. L. (2004). Business, advertising, and the social control of news. Journal of Communication Inquiry, 28(3), 233-252. doi:10.1177/0196859904264686

Croteau, D., \& Hoynes, W. (2001). The business of media: Corporate media and the public interest. Thousand Oaks: Sage.

Domingo, D., Quandt, T., Heinonen, A., Paulussen, S., Singer, J. B., \& Vujnovic, M. (2008). Participatory journalism practices in the media and beyond. Journalism Practice, 2(3), 326-342. doi:10.1080/17512780802281065

Engwall, L. (1981). Newspaper competition: A case for theories of oligopoly. Scandinavian Economic History Review, 29(2), 145-154.
Ess, C. M. (2014). Editor's introduction: Innovations in the newsroom - and beyond. Journal of Media Innovations, 1(2), 1-9.

Forsgård, H. (2006). Nya Åland 25 år [Nya Åland 25 years]. Mariehamn: Nya Åland.

Garrison, B. (2001). Diffusion of online information technologies in newspaper newsrooms. Journalism, 2(2), 221-239.

Gynnild, A. (2014). Journalism innovation leads to innovation journalism: The impact of computational exploration on changing mindsets. Journalism, 15(6), 713-730.

Härmälä, K., Helle, M., Heikkilä, H., \& Hytönen, K. (2012). Agile development of HBL+: Context matters. Helsinki: Next Media - A Tivit Programme.

Hester, J. B., \& Gibson, R. (2003). The economy and second-level agenda setting: A time-series analysis of economic news and public opinion about the economy. Journalism \& Mass Communication Quarterly, 80(1), 73-90.

Holm, A. B., Ulhøi, J. P., \& Uliyanova, A. (2012). Business model innovation: The Danish newspaper industry's response to the decline in traditional markets. World Media Economics \& Management Conference, Research report. http://papers.ssrn.com/ sol3/papers.cfm?abstract_id=2102615
Jenkins, H. (2006). Convergence culture: Where old and new media collide. New York: New York University Press.

Jönsson, A. M., \& Örnebring, H. (2011). User-generated content and the news. Journalism Practice, 5(2), 127-144. doi:10.1080/17512786.2010.501155

Kauhanen, E., Kaivo-Oja, J., \& Hautamäki, A. (2007). Innovaatiomedia: journalismi tulevaisuuden tekijänä [Innovation media: Journalism as maker of the future]. Helsinki: Palmenia.

Krumsvik, A. H., Skogerbø, E., \& Storsul, T. (2013). Size, ownership and innovation in newspapers. In T. Storsul, \& A. H. Krumsvik (Eds.), Media innovations: A multidisciplinary study of change (pp. 93-109). Göteborg: Nordicom.

Kumar, N., \& Puranam, P. (2012). India inside: The emerging innovation challenge to the west. Boston, Ma.: Harvard Business Press.

Küng, L. (2007). When innovation fails to disrupt: A multi-lens investigation of successful incumbent response to technological discontinuity: The launch of BBC news online. Jönköping: Jönköping International Business School.

Kvale, S. (2007). Doing interviews. Los Angeles: Sage. Lacy, S. (1989). A model of demand for news: Impact of competition on newspaper content. Journalism Quarterly, 66(1), 40-48. 
Lacy, S., Shaver, M. A., \& Cyr, C. S. (1996). The effects of public ownership and newspaper competition on the financial performance of newspaper corporations: A replication and extension. Journalism \& Mass Communication Quarterly, 73(2), 332-341.

Lasorsa, D. L. (1991). Effects of newspaper competition on public opinion diversity. Journalism \& Mass Communication Quarterly, 68(1-2), 38-47.

Levikintarkastus Oy. (2013). LT-levikkitilasto 2011. Helsinki: Levikintarkastus Oy.

Levikintarkastus Oy. (2014). LT-levikkitilasto 2012.

Helsinki: Levikintarkastus Oy.

Lundberg. B., Jansson, H., Lindqvist, R. \& JohanssonGammals, C. (2011). Förslag till mediepolitiskt program [Proposal for media policy programme] Mariehamn: Ålands landskapsregering.

Luther, M. (2009, 17 December). Holmgång på Åland [Duel on Åland]. Journalisti-Journalisten.

Martins, E., \& Terblanche, F. (2003). Building organisational culture that stimulates creativity and innovation. European Journal of Innovation Management, 6(1), 64-74.

Mattsson-Eklund, B. (1991). 100 år med Åland [100 years with Åland]. Mariehamn: Tidningen Åland.
Meier, K. (2007). Innovations in central European newsrooms. Journalism Practice, 1(1), 4-19. doi:10.1080/17512780601078803

Moring, T. (2007). Functional completeness in minority language media. Multilingual Matters, 138, 17.

Moring, T., \& Kivikuru, U. (2002). Svenskfinland - ett världsrekord i medier [Swedish-speaking Finland - A world record in media]. In T. Moring, \& A. Nordqvist (Eds.), Svenska medier i Finland [Swedish language media in Finland] (pp. 17-34). Helsingfors: Svenska social- och kommunalhögskolan.

Nordfors, D. (2004). The concept of innovation journalism and a programme for developing it. Innovation Journalism, 1(1), 1-14

Norman, D. A., \& Verganti, R. (2014). Incremental and radical innovation: Design research vs. technology and meaning change. Design Issues, 30(1), 78-96.

Nya Åland. (2015). Om Nya Åland [About Nya Åland]. Retrieved from http://www.nyan.ax/kontakt/om/

Nyre, L. (2014). Media design method. The Journal of Media Innovations, 1(1), 86-109.

Picard, R. G. (2010). Value creation and the future of news organizations: Why and how journalism must change to remain relevant in the twenty-first century. Lisbon: Media XII.
Picard, R. G. (2011). The economics and financing of media companies. New York: Fordham University Press.

Polansky, S. H., \& Hughes, D. W. W. (1986). Manageria innovation in newspaper organizations. Newspaper Research Journal, 8(1), 1-12. Retrieved from http:// search.ebscohost.com/login.aspx?direct $=$ true $\& \mathrm{db}=\mathrm{u}$ fh\&AN=18071720\&site $=$ ehost-live\&scope $=$ site

Pratt, A. C., \& Jeffcutt, P. (2009). Creativity, innovation and the cultural economy. London, New York: Routledge.

Press Commission 2004. (2006). Mångfald och räckvidd: Slutbetänkande av presskommittén 2004 [Diversity and reach: Final press commission report 2004]. Stockholm: Government of Sweden.

Rosse, J. N. (1980). The decline of direct newspaper competition. Journal of Communication, 30(2), 65-71.

Rothberg, I. (2010). Nyhetast på Åland: En studie i lokal mediekonkurrens och lokal nyhetsrapportering [Newshottest on Åland: A study in local media competition and local news reporting], Master's Thesis, University of Helsinki. 
Rundberg, M., \& Kinnunen, J. (2014). Turismens samhällsekonomiska betydelse för Åland 2013 [Socioeconomic importance of tourism on Åland 2013]. Mariehamn: ÅSUB.

Salokangas, R. (1999). From political to national, regional and local. The newspaper structure in Finland. Nordicom Review, 20(1), 31-76.

Schumpeter, J. A. (1934). The theory of economic development: An inquiry into profits, capital, credit, interest, and the business cycle. Cambridge, MA.: Harvard University Press.

Sjöholm, P. (2014). Alla tidningshus utom ett på minus [All newspaper companies except one is making a loss]. Retrieved from http://svenska.yle.fi/ artikel/2014/10/20/alla-tidningshus-utom-ett-paminus

Solis, B. (2014). The 2014 state of digital transformation. San Francisco: Altimeter.

Storsul, T., \& Krumsvik, A. H. (Eds.). (2013). Media innovations: A multidisciplinary study of change. Göteborg: Nordicom
Sulzberger, A. G. (2014). Innovation. New York: New York Times.

The Nordic Council. (2014). Population. Retrieved from http://www.norden.org/en/the-nordic-region/ population

Thorén, C. (2014). Print or perish? A study of inertia in a regional newspaper industry, Doctoral Thesis, Karlstad University.

Tingvall, P. G., \& Poldahl, A. (2006). Is there really an inverted U-shaped relation between competition and R\&D? Economics of Innovation and New Technology, 15(2), 101-118.

TNS Gallup. (2014). Kansallinen mediatutkimus. TNS Gallup. http://mediaauditfinland.fi/wp-content/ uploads/2014/o6/Circulations2013.pdf

Trappel, J. (2015). What to study when studying media and communication innovation? research design for the digital age. The Journal of Media Innovations, 2(1), 7-22.
Virranta, R. (2013). Suomi on hännänhuippu lehdistötuessa [Finland last in press subsidies]. Retrieved from http://www.suomenlehdisto.fi/ blog/2013/09/04/naapurit-nauttivat-tukia/

Wasström, M. (2002). Åland - ett särpräglat medielandskap [Åland - A peculiar media landscape]. In T. Moring, \& A. Nordqvist (Eds.), Svenska medier $i$ Finland [Swedish-language media in Finland] (pp. 107-126). Helsingfors: Svenska social- och kommunalhögskolan.

Westlund, O., \& Lewis, S. C. (2014). Agents of media innovations: Actors, actants, and audiences. Journal of Media Innovations, 1(2), 10-35.

Zabaleta, I., Ferré-Pavia, C., Gutierrez, A., Fernandez, I. \& Xamardo, N. (2014a). Future business innovation in minority language media. Journalism Practice, 8(5), 508-518. doi:10.108o/17512786.2014.895518 Zabaleta, I., Ferré-Pavia, C., Gutierrez, A., Fernandez, I., \& Xamardo, N. (2014b). European minority language media and journalism: Framing their marginal reality. International Communication Gazette, 76(3), 275-295. doi:10.1177/1748048513516907 